\title{
STUDIES ON THE STOMACH PARASITE FAUNA OF DONKEYS (EQUUS ASINUS)
}

\begin{abstract}
I.S. El-Shahawy
Parasitology Department- Faculty of Veterinary Medicine - South Valley university.

\section{ABSTRACT}

The present study was carried out to evaluate the infection rates, numbers of stomach parasites, some morphological criteria of the identified parasites as well as the pathological lesions produced among donkeys at necropsy. In this study the overall prevalence of the gastric parasites among donkeys is $90.7 \%$ and the most prevalent species is Gasteroph-ilus species (69.4\%) followed by Habronema species (35.2\%). Gaster-ophilus intestinalis and Gasterophilus nasalis as well as Habronema muscae,Habronema megastoma and Habronema microstoma were recorded in this study. The morphological criteria and the associated pathological lesion of the fore mentioned parasites are completely studied and discussed.
\end{abstract}

\section{INTRODUCTION}

Donkeys is are considered an important animal in the economy of landless as well as were also used for pulling carts and carrying loads (including riders). Though not as fast as horses, donkeys are long-lived, cheaper to maintain, have great endurance, and are agile on poor tracks so they remain of crucial economic importance in many developing countries. Today donkeys are becoming increasingly popular as recreation and companion animals as they are ridden or used to pull wagons and still function as pack animals in wilderness adventures. Lyons et. al. (2000).

Internal parasites are the greatest cause of colic in donkeys and are often a causative or contributing factor in many respiratory, digestive and performance problems. Though parasites are a constant problem for donkeys owners. However, contrary to popular belief, donkeys can have a 
dangerous, damaging parasite burden and appear externally healthy, fat and shiny. The prevalence and intensity of stomach parasites in donkeys are previously studied by some authors Hilali et. al. (1987); Egri et. al. (1995) ;Hoglund et. al. (1997); Agneessens et. al. (1998); Lyons et. al. (2000) and Sequeira et. al. (2001)

The main objective of the present investigation was to evaluate the infection rates and numbers of stomach parasites, some morphological criteria of the identified species as well as the pathological lesion produced among donkeys at necropsy.

\section{MATERIAL \& METHOD}

\section{1) Animals \& sampling:}

one hundred and eight donkeys originating from different villages of Kafr El-Sheikh province and older than 2months were examined postmortem for stomach parasites( worms and arthropods larvae). These donkeys were submitted for Kafr El-Sheikh city zoo which are slaughtered daily for feeding of wild carnivores. The stomach of each donkey was ligatured on the two extremities(cardiac and pyloric regions)and isolated. It was opened with scissors along the great curvature. The gastric content was examined grossly for the presence of the adult forms of parasites as the gastric mucus was collected by scraping the mucosa with a lancet and mixed in $50 \mathrm{ml}$ of tap water. The suspension was filtrated on several sieves with decreasing meshes $(1000 \mu \mathrm{m}, 100 \mu \mathrm{m}, 80 \mu \mathrm{m}, 40 \mu \mathrm{m})$. Each sieve was inspected grossly and the worms found were preserved in alcoholic glycerin solution. The sieves were then washed and formalin was added to the rinsing water to obtain a $5 \%$ formalin solution. This solution was left to decant for one hour.The supernatant was then eliminated and the parasites were searched in the residue of sedimentation under a microscope at low magnification (x10) as well as the larval stage of arthropod parasites were completely studied.The identification of the collected parasites were performed according to EUZEBY(1958); LICHTENFELS (1975) and Soulsby (1982). 


\section{2) Histopathological studies:}

Tissue specimens were taken from stomach, fixed immediately in $10 \%$ formalin saline, embedded in paraffin, sectioned and stained with $\mathrm{H} \& \mathrm{E}$ stain and examined microscopically to determine the pathological changes. according to Carleton et. al. (1967)

\section{RESULTS}

\section{A- Prevalence of the detected parasites:}

The present study showed that the over all prevalence of the stomach parasites among donkeys was $90.7 \%$ (98 out of 108) and the most prevalent species was Gasterophilus species larvae with an infection rate of 69.4\% followed by Habronema species (35.2\%).

Regarding to Gasterophilus species, Gasterophilus intestinalis and Gasterophilus nasalis larvae was recorded in this study. The most predominant species was Gasterophilus intestinalis larvae with an infection rate of $51 \%$ while Gasterophilus nasalis represent $18.5 \%$ of the examined stomach.

The percentage of donkeys infected with 1-50 and 51-100 larvae was $66.6 \%$ and $33.3 \%$ respectively for both species.Concerning the Habronema species, 3 species were recovered from the stomach of donkeys identified as Habronema muscae with an infection rate of $18.5 \%$ followed by Habr-onema megastoma (11.1\%) and Habronema microstoma represent $5.5 \%$ of the examined stomach.

Mixed infection of both Gasterophilus larvae and Habronema species represent $4.6 \%$ of the examined stomach. Table \& Fig. (1).

\section{B- Some morphological character of the identified parasites:}

\section{1) Habronema species:}

Adult worm are white in color measuring $10-15 \mathrm{~mm}$ long male; 12 $25 \mathrm{~mm}$ long female, the anterior end showing 2 lips surrounding the mouth opening and the pharynx which is cylindrical in Habronema muscae (plate 1; A); funnel shaped and there is a constriction between Kafr El-Sheikh Vet. Med. J. Vol. 4 No. 1 (2006) 
the lips and the body in Habronema megastoma (plate 1; B), while Habronema microstoma has an inverted funnel shape pharynx (plate 1; C). The posterior end of male is spirally coiled with a wide caudal alae and unequal spicules while the vulva is located near the middle third of the female body (plate 1; D\& E).

\section{2) Gasterophilus species:}

\section{2-1) First stage larvae:}

$0.5 \mathrm{~cm}$ long, body covered with small spines, has equal oral hooks and D-shaped posterior spiracle which provided with 2 straight respiratory slits.

\section{2-2) Second stage larvae:}

$1 \mathrm{~cm}$ long, body covered with small spines, has equal oral hooks and D- shaped posterior spiracle which provided with 2 straight respiratory slits.

\section{2-3) Third stage larvae:}

Mature larvae of Gasterophilus species are large, stout and there are bands of large spines on all segments except the last one, a pair of large hooks which are equal, projecting anteroirly and kidney shaped posterior spiracle provided with three longitudinal straight respiratory slits.( plate $2, \mathrm{~A}, \mathrm{~B}, \mathrm{C}, \mathrm{D} \& \mathrm{E}$ )

\section{* Species differentiation of Gasterophilus depending on the morpho- logical character:}

\section{Gasterophilus intestinalis:}

Site: cardiac region and cluster at boundary of glandular and nonglandular epithelium of the stomach

Mature larvae characterized by the following criteria $3 \mathrm{~cm}$ long, red in color when fresh. Head segment provided only with lateral groups of denticles. Spines on the ventral surface of the segment arranged in two rows which has a characteristic blunt tips. Mouth hooks are not uniformly curved dorsally but provided with shallow depression. The recurved maxillae are evident as the elements of the cephalo-pharyngeal skeleton.Plate(3). 


\section{Gasterophilus nasalis:}

Site: pylorus and first part of the duodenum.

Characterized by $2 \mathrm{~cm}$ long, pale yellow in color when fresh. The first three body segments are somewhat conical in shape. Spines on the ventral surface of the segment arranged in single row which has a characteristic pointed tips.Mouth hooks are some what curved dorsally with clear shallow depression. Plate (4).

\section{C- Histopathological results:}

Gross lesion: showed that gastric ulcer produced by Gasterophilus species larvae which characterized by round areas (millet size) deeper in mucosa of stomach. The ulcer are demarcated and has a raised borders with depressed center in addition to the stomach wall is redden and thickened in size . Plate.(5)

\section{Microscopically:}

Adult Habronema worms were detected inside the gastric gland.The gastric gland suffered from destruction in the epithelial lining inside the lumen,others showed hyperplasia of the epithelial lining inside the lumen. Fig.(2).

While the lesion produced by Gasterophilus species larvae was con-cluded in desquamation in the epithelial lining of the stomach villae with numerous leukocytic infiltration mainly lymphocyte, eosinophile and fibrous tissue proliferation in the gastric mucosa and submucosa due to parasitic gastritis Fig. (3). In addition to the gastric ulcer were detected due to attachment of large numbers of Gasterophilus species larvae which characterized by desquamation of the epithelial lining of gastric villae deeply into the mucosa and submucosa which covered by mucofibrinous exudates infiltrated with numerous inflammatory cells mainly eosinophils and lymphocyte. Fig. (4). 


\section{DISCUSSION}

In the present study the overall prevalence of stomach parasites among donkeys was 90.7\% (98 out of 108) and the most prevalent species was Gasterophilus species larvae with an infection rate of $69.4 \%$ followed by Habronema species (35.2\%). The above mentioned results varied with that recorded by Tolliver et. al.(1987) who recorded a low prevalence for Gasterophilus species $(62.7 \%)$ and high infection rate for Habronema species (56.9\%) among horses in Kentucky.

Regarding to the Gasterophilus species, the obtained results showed that the most prevalent species was Gasterophilus intestinalis with total incidence of 51\%.This result agreed with that reported by $\boldsymbol{E d w a r d s}(\mathbf{1 9 8 2})$ who found the prevalence of Gasterophilus intestinalis among horses in northern England was 52.7\%;nearly similar to that stated by Agneessens et. al. (1998) in Belgium (58.\%) and varied with those recorded previously by Hilali et. al. (1987); Pandy and Eysker (1988); Bucknell et. al. (1995) and Egri et. al. (1995) who reported a high prevalence of Gasterophilus intestinalis among donkeys 98.3\% in Egypt; 100\% in Zimbabwe; $81 \%$ in Australia and $84.53 \%$ in Russia respectively while the low prevalence were recorded by Dunsmore and Jue (1985);Beeltiz et.al.(1996); Hoglund et. al. (1997) and Lyons et. al.(2000) who found the total incidence were $36.4 \%$ in western Australia; $21.6 \%$ in Germany ;12.3\% in Sweden and $14 \%$ in central Kentucky respectively. These variation might be attributed to periodic activity of adult bot fly, pasture contamination and climatic differences. For Gasterophilus nasalis the present work showed that the total prevalence was $18.5 \%$ and this result was nearly similar to Sequeira et. al.(2001) which recorded the prevalence Gasterophilus nasalis was $16.84 \%$ in brazil and disagreed with that obtained by Egri et. al. (1995)and Lyons et. al.(2000) who recorded a low infection rate of Gasterophilus nasalis among horses $10.41 \%$ and $2 \%$ in Kentucky and Russia respectively. this variation might be attributed to the difference in Kafr El-Sheikh Vet. Med. J. Vol. 4 No. 1 (2006) 
climatic condition and pasture contamination.In this study the percentage of donkeys that infected with 1-50 and 50-100 larvae was $66.6 \%$ and $33.3 \%$ respectively for both species. This result agreed with that Agneessens et. al. (1998) who found the majority of horses $(67 \%)$ harbored less than 50 larvae and disagreed with that recorded by Hilali et. al.(1987)who found the percentage of infected donkeys with 1-100 larvae was $72 \%$ for Gasterophilus intestinalis and $76.3 \%$ for Gasterophilus nasalis. This variation might be attributed to the adult fly activity and also to the locality.

Regarding to Habronema species, the results in the present study disagreed with that recorded by Fayek et. al. (1996) who stated the prevalence of Habronema species among donkeys in Kafr El-Sheikh city was $88 \%$ while the low infection rate $(4.3 \%)$ was recorded by Brogsteede and Vanbeek(1998) among horses in Netherlands.3 Habronema species were recorded in this study Habronema muscae, Habronema megastoma and Habronema microstoma with an infection rate of $18.5 \%, 11.1 \%$ and $5.5 \%$ respectively. These results disagreed with that previously recorded by Pandy et. al. (1992); Dunsmore and tnie(1985);Pandy and Eysker (1988) and Hoglund et. al.(1997) whose reported the total prevalence of Habronema muscae and Habronema megastoma was $89.7 \%$ and $1.1 \%$ in western Australia; 35.3\% and 66.2\% in Morocco; $85.7 \%$ and $78.5 \%$ in Zimbabwe and $1.1 \%$ in Sweden respectively. The variation in the result might be attributed to distribution and activity of the intermediate host as well as susceptibility to the infection.

Morphological study of the identified parasites was nearly similar to that obtained by LICHTENFELS (1975); EUZEBY(1958); Soulsby (1982) and Wall and Shearer (2001).

Dealing with histopathological studies, the obtained results agreed with that recoded by Sequeira et. al.(2001). 
The observed high prevalence of the stomach parasites infection among donkeys population confirm that gasterophilosis has be taken into serious consideration and prophylactic measures might be indicated.

Table (1): Prevalence of the detected stomach parasites.

\begin{tabular}{|c||c||c|c|}
\hline Species & No. of examined & $+\boldsymbol{+} \boldsymbol{e}$ & $\boldsymbol{\%}$ \\
\hline \hline Habronema muscae & 108 & 20 & 18.5 \\
\hline Habronema megastoma & 108 & 12 & 11.1 \\
\hline \multirow{2yyy}{*}{ Habronema microstoma } & 108 & 6 & 5.5 \\
\hline Gasterophilus intestinalis & 108 & 55 & 51 \\
\hline Gasterophilus nasalis & 108 & 20 & 18.5 \\
\hline Mixed infection & 108 & 5 & 4.6 \\
\hline
\end{tabular}

Fig. (1): Prevalence of the detected stomach parasites.

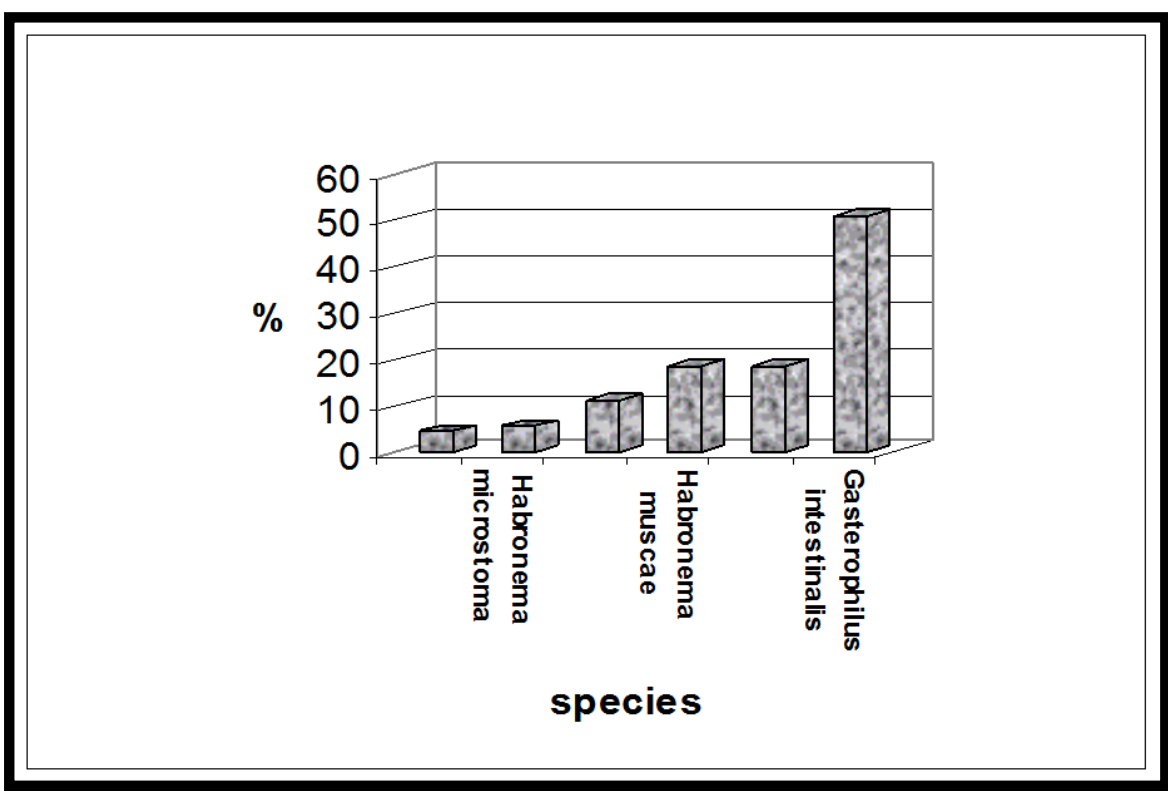

$\overline{\text { Kafr El-Sheikh Vet. Med. J. Vol. } 4 \text { No. } 1 \text { (2006) }}$ 


\section{Plate (1):}

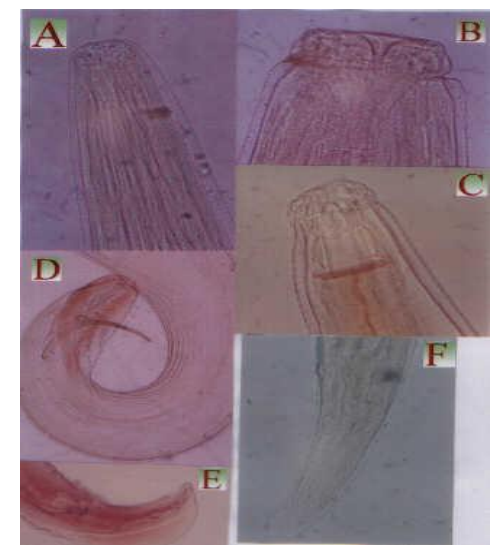
A) Habronema muscae (x 500)
B) Habronema megastoma (x 500)
C) Habronema microstoma (x 500)
D) Male posterior end (x500)
E) Female posterior end (x500)

Plate (2):

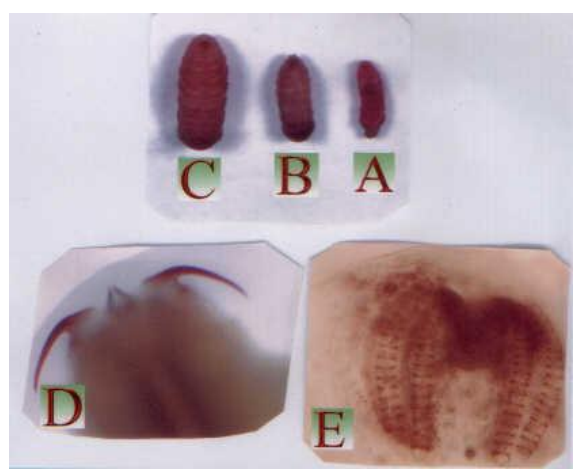
A) Gasterophilus intestinalis $1^{\text {st }}$ stage larvae
B) Gasterophilus intestinalis $2^{\text {nd }}$ stage larvae
C) Gasterophilus intestinalis $3^{\text {rd }}$ stage larvae
D) Anterior end of $1^{\text {st }}$ stage larvae
E) Posterior spiracle $1^{\text {st }} \& 2^{\text {nd }}$ stage larvae 


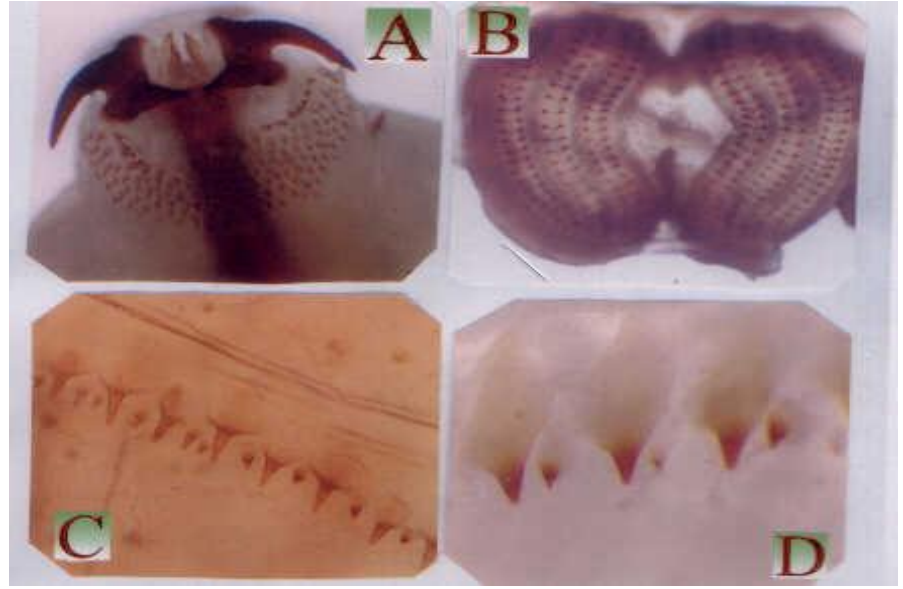

Plate (3): Gasterophilus intestinalis
A) Anterior end
B) Posterior spiracle
C \& D) Body spines

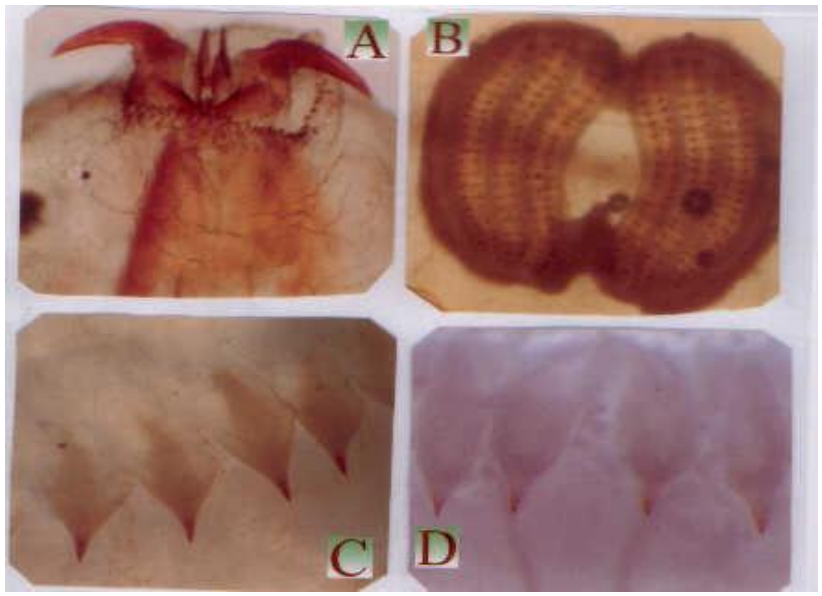

Plate (4): Gasterophilus nasalis
A) Anterior end
B) Posterior spiracle

$\overline{\text { Kafr El-Sheikh Vet. Med. J. Vol. } 4 \text { No. } 1 \text { (2006) }}$ 
C\& D) Body spines

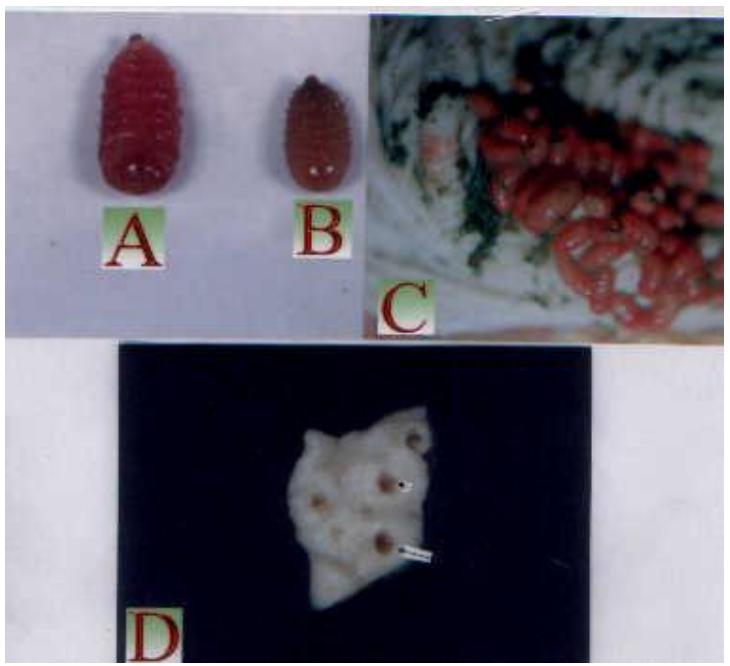

Plate (5)

A) Gasterophilus intestinalis mature larvae (Fresh specimen)

B) Gasterophilus nasalis mature larvae (Fresh specimen)

C) Gastric ulcers (arrow)

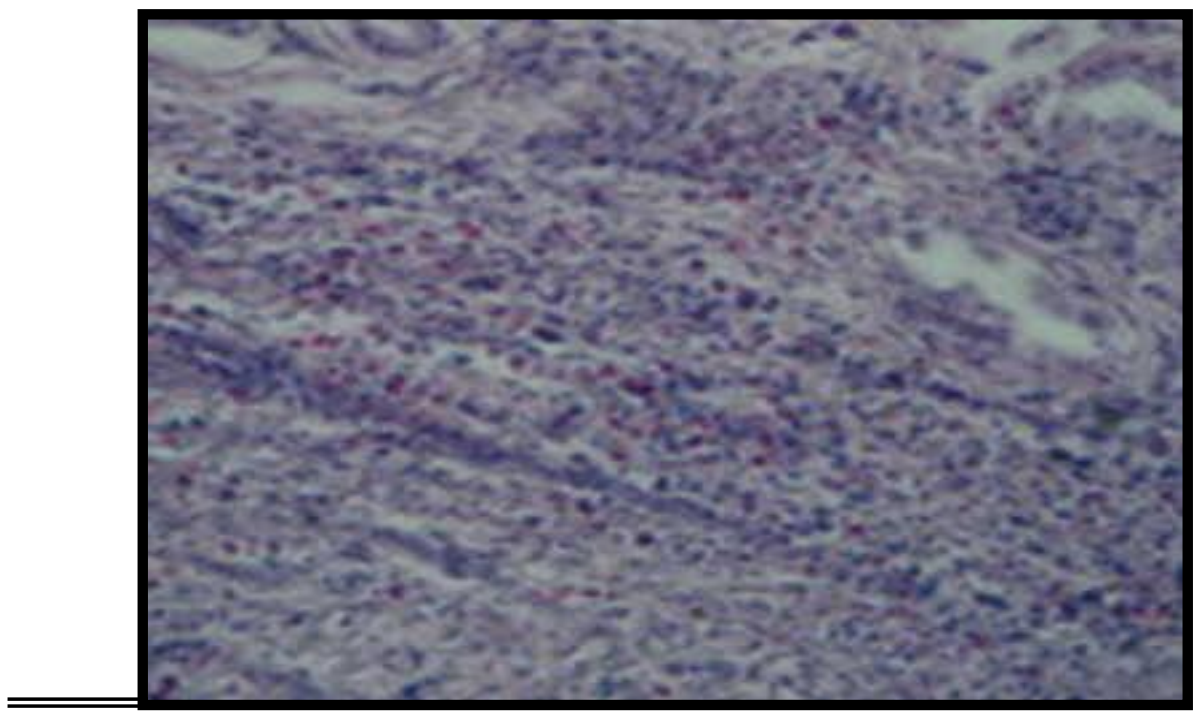

Kafr El-Sheikh Vet. Med. J. Vol. 4 No. 1 (2006) 
Fig.(2): Stomach of horse infected with Habronema species showing desquamation in the epithelial lining with severe leukocytic infiltration in mucosa and sub mucosa (H\&E, x 1200).

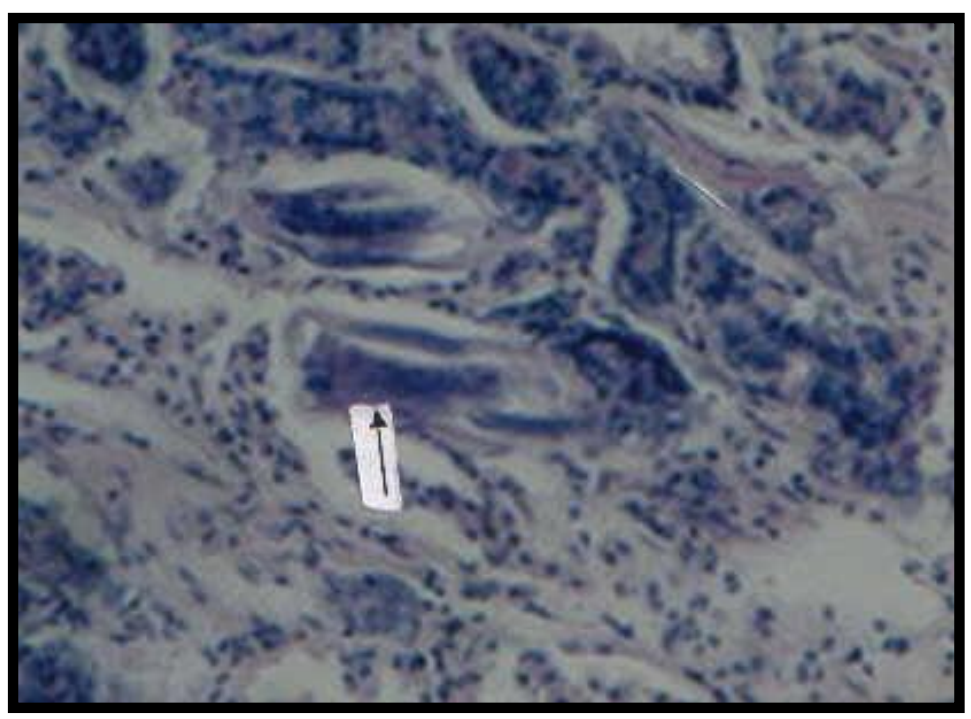

Fig. (3): Stomach of horse infected with Habronema species showing large worm inside the gastric gland (arrow) (H\&E, x 1200)

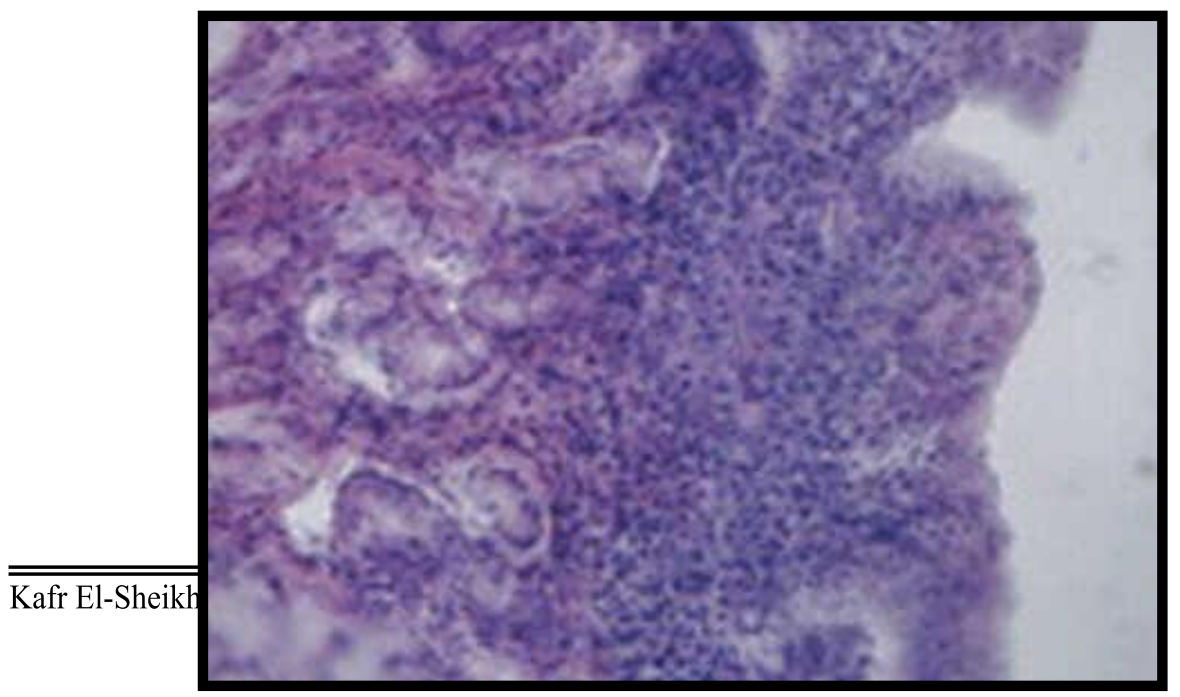


Fig. (4): Stomach of horse infected with Gasterophilus species showing desquamation in the gastric wall which covered by mucofibrinous exudates infiltrated with inflammatory cells mainly eosinophile \& lymphocyte (H\&E, x 150).

\section{REFERENCES}

- Agneessens, J.; Engelen, S.; Debever, P. and Vercruysse, J. (1998): Gasterophilus intestinalis infections in Belgium.Vet. Parasitol., 77: 199 -204.

- Beelitz, P.; Gobel, E. and Gothe, R. (1996): Spectrum of species and incidence of endoparasites in foals and their mother mares from breeding farms with and without anthelmintic prophylaxis in upper Bavaria. Tierarztl. Prax., 24:48-54.

- Brogsteede and Vanbeek (1998): Parasites of stomach and small intestine of 70horses slaughtered in the Netherlands. Vet. Q.,20(1): $31-34$.

- Bucknell,D.;Gasser,R. and Beveridge, I.(1995): The prevalence and epidemiology of gastrointestinal parasites of horses in Victoria, Austr-alia. Int. J. Parasitol., 25(6):711-724.

- Carleton, M.A.; Drury, R.A.; Willinton, F.A. and Carneron, $H$. (1967): Carleton's histopathological techniques. $4^{\text {th }}$ Ed.Oxford University press, Toronto, 129-130.

- Dunsmore, J. and Jue, P.(1985): Prevalence and epidemiology of the major gastrointestinal parasites of horses in Perth, Western Australia. Equine Vet. J., 17:208-213.

- Edwards, G.(1982): The prevalence of Gasterophilus intestinalis in horses in northern England and Wales. Vet. Parasitol., 11: 215-222. 
- Egri, B.; Sarkozy, P. and Banhidy, G.(1995): Prevalence of botfly larvae and lice in studs of North Caucasus(Stawropol country,Russia). Acta Vet. Hung., 43:287-289.

- EUZEBY,[J. (1958): Diagnostic expérimental des helminthoses anim-ales -Travaux pratiques d'helminthologie vétérinaire,Vigot Frères Ed., Paris,: 224-225.

- Fayek, S.; Amer, O. and Abdel Whab, T. (1996): Further studies on the nematode parasites of Equines in Egypt. J. Egypt. Vet. Med. Ass., 56(3): 313-329.

- Hilali,M.;Derhalli,F.and Baraka, A. (1987): Incidence and monthly prevalence of Gasterophilus species larvae (Diptera: Gasterophilidae) in the stomach of donkeys (Equus asinus) in Egypt. Vet. Parasitol., 23: 297-305.

- Hoglund,J.; Liungstrom,B.;Nilsson, O.; Lundquist, H.; Osterman, E. and Uggla, A. (1997): Occurrence of Gasterophilus intestinalis and some parasitic nematodes of horses in Sweden. Acta Vet. Scand., 38: 157-165.

- LICHTENFELS,J.(1975):Helminthes of domestic equids. Illustrated keys to genera and species with emphasis on North America forms.Proc. Helminthol. Soc. Wash. (special issue), 42, p.16-63.

- Lyons, E.; Swerczek, T; Tolliver,S;Bair,H; Drudge, J. and Ennis, L. (2000): Prevalence of selected species of internal para-sites in equids at necropsy in central Kentucky. Vet. Parasitol., 92: 51-62.

- Pandy, V.and Eysker,M. (1988): Parasites of the stomach in donkeys of the highveld of Zimbabwe. Vet. Q.,(4): 246-248.

- Pandy, V.; Ouhelli, H. and Verhulst, A. (1992): Epidemiological observations on Gasterophilus intestinalis and 
Gasterophilus nasalis in donkeys from Morocco. Vet. Parasitol., 41: 285-292.

- Sequeira,J.;Tostes, R.and Oliveira,T.(2001): Prevalence and macro-and microscopic lesion produced by Gasterophilus nasalis (Diptera: Osteridae)in the Botucatu region,Sp,Brazil. Vet.Parasitol., 13:261-266.

- Soulsby, E.J. (1982):Helminthes, Arthropods and Protozoa of domes-ticated animals. Bailliere Tindall Ltd, $7^{\text {th }} \mathrm{ed}$., British Library, London.

- Tolliver S.;Lyons E. and Drudge J.(1987): Prevalence of internal parasites in horses in critical tests of activity of parasiticides over a 28 -year period (1956-1983) in Kentucky. Vet Parasitol.,23(3-4):273-84.

- Wall, R. and Shearer, D. (2001): Veterinary ectoparasites: Biology, Pathology and control. $2^{\text {nd }}$ (Ed.). Blackwell Science ltd. Oxford.

\section{الملخص العربي}

أجريت هذه الدراسة علي عدد 108 حمارا لمعرفة نسب الإصابة للطفليات المختلفة التي تصيب المعدة. وأوضحت النتائج أن نسبة الإصابة الكلية 7و 90\% وتم التعرف علي نوعين من الطفيليات نوع من الديدان الاسطوانية والنوع الأخر ينتمي إلي فصيلة الحشرات. تم حساب نسب الإصـابة لكل نوع علي حدة وكذلك تم توصيف هذه الطفليات توصيفا مورفولوجيا وكذا التأثير المرضي المصاحب لها. 